\title{
Alexandra Deglise: Artist Statement and Digital Portfolio
}

\author{
Alexandra Deglise \\ Charlottesville, Virginia
}

Master in Journalism, Lyon 3 University, 2007

Bachelor in History, Burgundy University, 2003

A Thesis presented to the Graduate Faculty of the University of Virginia in Candidacy for the Degree of Master of Fine Arts in Acting

\section{Department of Drama}

University of Virginia

May 2016 


\section{Abstract}

This document contains Alexandra Deglise's Masters of Fine Arts Thesis produced for the completion of the 2016 Professional Actor Training Program at the University of Virginia. It includes a digital portfolio of the following performances: The Bone or the Ring, by Alexandra Deglise, My Imaginary Kid, by Leonard D. Grissom, and Padam Padam, by Henri Contet, along with an Artist Statement and Journal of the Creation Process. This thesis will mainly be used as a promotional and grant research package. 


\section{Table of Contents}

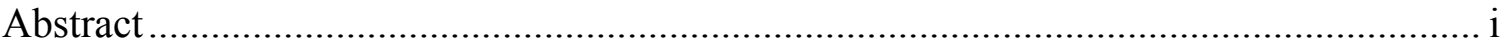

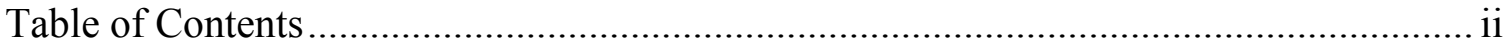

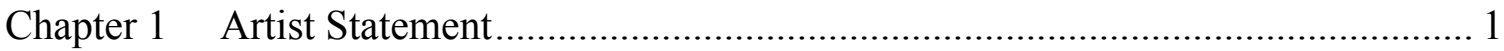

Chapter 2 Journal of the Creation Process ................................................................. 4

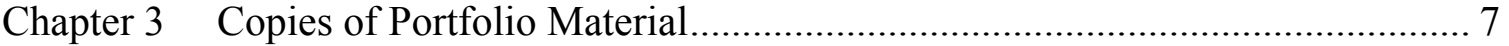

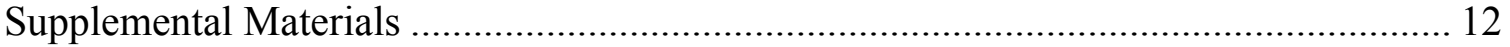




\section{Chapter 1 Artist Statement}

\section{Introduction}

When I joined the UVA Acting MFA program in August 2014, I meant to achieve several goals. First, technique: get in-depth training in Voice and Speech, further my education in movement, and explore varied theatrical techniques/styles. Second, craftsmanship: be inspired and challenged to create a theatre piece through Devised Work. Third, professional contacts: extend my network in the industry and initiate new relationships with theater/movie makers. Finally, playwriting breakthrough: resume working on a play I started back in 2009. I am glad to say all these goals have been reached.

My training over the past two years has enabled me to become a fully developed artist; ready to create and produce work that I believe can make a meaningful contribution to the contemporary theater landscape.

\section{What kind of artist? How do I create?}

I am an actor and a teacher, and because I have stories in me that need to be fully expressed and embodied I am also a playwright.

The play I am developing combines various media, genres and performing traditions. The diverse cultural backgrounds that inform my work — born in France, I grew up on the Caribbean island of Martinique and became an American citizen in 2013- 
are an infinite source of inspiration; I believe that stories have to be told in order to foster open-mindedness about cultural variety in artistic expression, in my case a family tale from the West-Indies told through a Japanese dance form. My approach mixes dance, singing, and a foreign performing tradition in order to challenge audience expectation.

\section{Inspirations, personal influences}

One of my direct personal inspirations is Heather Raffo, an actor and playwright who was in residence at UVa for a week in March 2015 when we produced 9 Parts of Desire, a solo show she wrote as an acting student at The Old Globe USD Graduate Acting MFA Program. She felt compelled to write because she found few interesting roles to play and none that addressed her identity as an American/Iraqi woman. Working with Heather was deeply inspirational. She was passionate about her art and sharing it with an audience directly through Q\&As and debates. In creating work for herself, she served a greater purpose: telling a story of which American people were not aware, and thereby helping them expand their world consciousness.

\section{Artistic process and techniques}

Movement is at the core of my acting. I trained in Body Dynamics ${ }^{\mathrm{TM}}$ in New York, a technique designed to free the actor from chronic tension, which promotes full range of expression in performance. The play I am currently developing, Raphael's Islands, mixes Martinican traditional dances, original music and songs, and the Japanese technique Butoh ("dance of darkness"). I believe Butoh is the best way to express the darkness behind the commonly held vision of Martinique. I discovered this technique 
through a workshop by Yumiko Yoshioka, at the Japanese Society in New York in April 2014. I then moved to Charlottesville for my MFA training and, while doing research on the technique in my spare time over the summer of 2015, I discovered that a Butoh specialist, Julia Vessey, works at James Madison University. She trained with the Tokyobased studio Dairakudakan and introduced me to one of their dancers, Daiichiro Yuyama. I am going for my first Japanese-based Butoh workshop taught by Dairakudakan in Nagano this coming August, and hope to go back to Tokyo in the Spring of 2017 for an in-depth three-month workshop with the company.

\section{What does it mean to me?}

My intention with Raphael's Islands is to bring peace and understanding to a population which does not reflect or recognize the self-abuse it has been perpetrating since the French abolition of slavery in 1848. The Martinique I grew up in is frozen in time, unable to free itself from a foundational trauma that still defines its essence today. As an artist writing this play, I took on a responsibility: to encourage healing in my community by shining a light on its underlying darkness, be it an ugly one, far from the trite postcard imagery of white sand beaches, colorful cocktails, and carefree living. Hopefully expressing this duality, with the hope that it will help some Martinicans "break free from the chains" that are still at the roots of their identity. I will do it as honestly as possible, with one firm intention in mind: to bring dignity and self-ownership to a community that has not yet found them. 


\section{Chapter 2 Journal of the Creation Process}

My research and creative process in the search for monologues for my digital portfolio started on December 10th 2015. That afternoon, we had a meeting with Michael Duni, from arvold.casting (Charlottesville), who would be our director, cinematographer and video editor, and Professor Richard Warner, who would assist Michael during the shoots. This meeting established the number of pieces shot and their length. Deadlines for their production and postproduction were also set that day.

We therefore knew that we had to be back from winter break with four to five pieces to share them in class with Kate Burke, our advisor and coach on this project. These pieces had to be original, in the public domain or we needed the author's permission to use them.

I reached out to Leonard D. Grissom and Denise Stewart, playwrights and professors at UVA and they both very generously sent materials to me. I kept one from Leonard Grissom to which I connected, and I edited it to suit my age range.

Back at UVA, we started our coaching sessions with Kate Burke. Most of the pieces we brought in were monologues we had written ourselves. We read them and decided which were worth keeping. From five pieces we skimmed down to two each. In spite of my best efforts to write concise monologues, once spoken and embodied, they were over one minute. The goal was to find a full arc in less than a minute, and with everybody's help and feedback I eventually succeeded. 
After the pieces were the right length, Kate helped us find the tone, pace and contrast of each to show our range. At first, we treated these monologues as theater pieces. Then, we recorded them on camera to see what adjustments needed to be made for on-screen truth. The characters' life and thought process had to be internalized; movement needed to be tamed and reduced to a minimum, an eye movement replacing a head turn or hand gesture.

During this fine-tuning rehearsal process, Les Rorick, our liaison with Michael Duni, created a detailed production spreadsheet. All our videos — monologues, songs and interviews - were scheduled for filming over two weekends: February 26-28 and March 3-4. We had booked space at the Drama Department, at the Architecture School and at Oakhart, a local bar-restaurant. Those of us who were not scheduled to be on camera one weekend could assist Michael and Richard with light and set.

My song, Padam Padam by Henry Contet, accompanied by Greg Harris, was recorded on February $26^{\text {th }}$. We had set the Drama Department's grand piano in a corner of the lobby and we did it in one shot. The process had to be expedited because the Box Office was open and we couldn't ask everybody to hold his or her activities because of our shoot.

My interview was shot on March $3^{\text {rd }}$ and this process was much more relaxed. This time, we were in the Caplin Theater and had the space booked for this purpose. I came with a script I had loosely memorized. For the first two minutes, Michael let me share what I had prepared and then asked a few questions about the program. Finally, he asked for a joke, explaining it would allow us to appear more relaxed and open in front of the camera. 
Working on our monologues the next day was a real treat. We arrived on location at Oakhart around 9:30am, prepared the set and started shooting. As for a scene, Michael encouraged us to use a partner in order to be fed by their reactions. I felt a lot more grounded than I would have in a solo theater monologue. Michael directed us and gave adjustments when necessary. Sometimes he would ask us to go in a completely different direction, turning what was supposed to be a drama into a comedy. Richard Warner was also on set to coach us. His expertize and grounded guidance were most appreciated.

After seeing the result on screen I can tell one thing: I now understand that for oncamera work less is more. Although we seriously worked, during our preparation phase, on internalizing the character's emotional life as much as possible, I still saw too much unnecessary movement in my videos. It is challenging to trust that everything can happen through a gaze on camera.

The whole experience, working or observing others, was extremely pleasant and educational. Furthermore, working with Michael Duni was a great opportunity to start a relationship, which I hope will grow in the future. He has worked closely with us and on our materials for weeks. He has a clear idea of what we have to offer and I am sure this will facilitate our collaboration with arvold.casting, should the opportunity present itself. 


\title{
Chapter 3 Copies of Portfolio Material
}

\author{
Monologues:
}

\section{1- The Bone or the Ring}

"What if we didn't have to have that sort of old fashioned relationship? It's an ideal society imposes on us. I am never getting married; it's a lie!

I mean, what if I want to bone that guy right there. I should be able to do it! What if you want to screw that girl in the bathroom? You should be able to do it! We are animals and it's all right!

We need to talk about this before we are going too far, with different ideas of what love is. What are you doing? Hhh! Jimmy... is that... a ring?"

\section{2- My Imaginary Kid}

"You, my dear, are seriously...

It might interest you to know...I never had a child.

Oh, I tried. I never used birth control. I was with this wonderful guy for five years and... nothing. He already had a couple of kids so I know the 'problem' wasn't his. And so because of all this, my dear, I am able to say two things with absolute certainty: one--you are not my daughter; and two - for a fifteen year-old, you are seriously fucked up!" 
* This second monologue comes from material the playwright Leonard D. Grissom sent me with his permission "to cut, rearrange, or change the language to suit [me]." Thanks very much to him. 
Padam Padam lyrics:

Cet air qui m'obsède jour et nuit Cet air n'est pas né d'aujourd'hui Il vient d'aussi loin que je viens Trainé par cent mille musiciens

Un jour cet air me rendra folle Cent fois j'ai voulu dire pourquoi Mais il m'a coupé la parole Il parle toujours avant moi Et sa voix couvre ma voix

Padam, padam, padam

Il arrive en courant derrière moi Padam, padam, padam Il me fait le coup du souviens-toi Padam, padam, padam

C'est un air qui me montre du doigt

Et je traîne après moi comme un drôle d'erreur

Cet air qui sait tout par coeur

Il dit, "Rappelle-toi tes amours Rappelle-toi puisque c'est ton tour 'y a pas d'raison pour qu'tu n'pleures pas Avec tes souvenirs sur les bras"

Et moi je revois ceux qui restent Mes vingt ans font battre tambour Je vois s'entrebattre des gestes

Toute la comédie des amours

Sur cet air qui va toujours

Padam, padam, padam

Des "Je t'aime" de quatorze-Juillet

Padam, padam, padam

Des "Toujours" qu'on achète au rabais

Padam, padam, padam

Des "Veux-tu" en voilà par paquets

Et tout ça pour tomber juste au coin d'la rue Sur l'air qui m'a reconnue 
Écoutez le chahut qu'il me fait Comme si tout mon passé défilait

Faut garder du chagrin pour après

J'en ai tout un solfège sur cet air qui bat

Qui bat comme un coeur de bois 
Personal statement transcript:

“I'm Alexandra Deglise, and I've spent almost two years here at UVa studying and teaching acting.

My world as an actor, and as a human being, has expanded tremendously. I now have all the tools I need to build a character or to find out how to tell a story I really want to tell. I want to tell stories which have to be told, so hopefully they touch people and, ultimately, I hope they help to make the world a better place.

It's important, as artists, to be able to convey what acting is and to share it with other people. We teach them and they see us at night on stage working.

I'm really proud of working here because some of my students have taken the leap and have moved to New York to learn acting in professional studios in New York and to start acting on off off Broadway and I really really hope that they will make it. Thank you for watching.”

* Music: www.bensound.com 


\section{Supplemental Materials}

Headshot

Resume

Bio

Digital Content:

- Personal Statement

- Two Monologues

- Padam Padam (Henry Contet) 


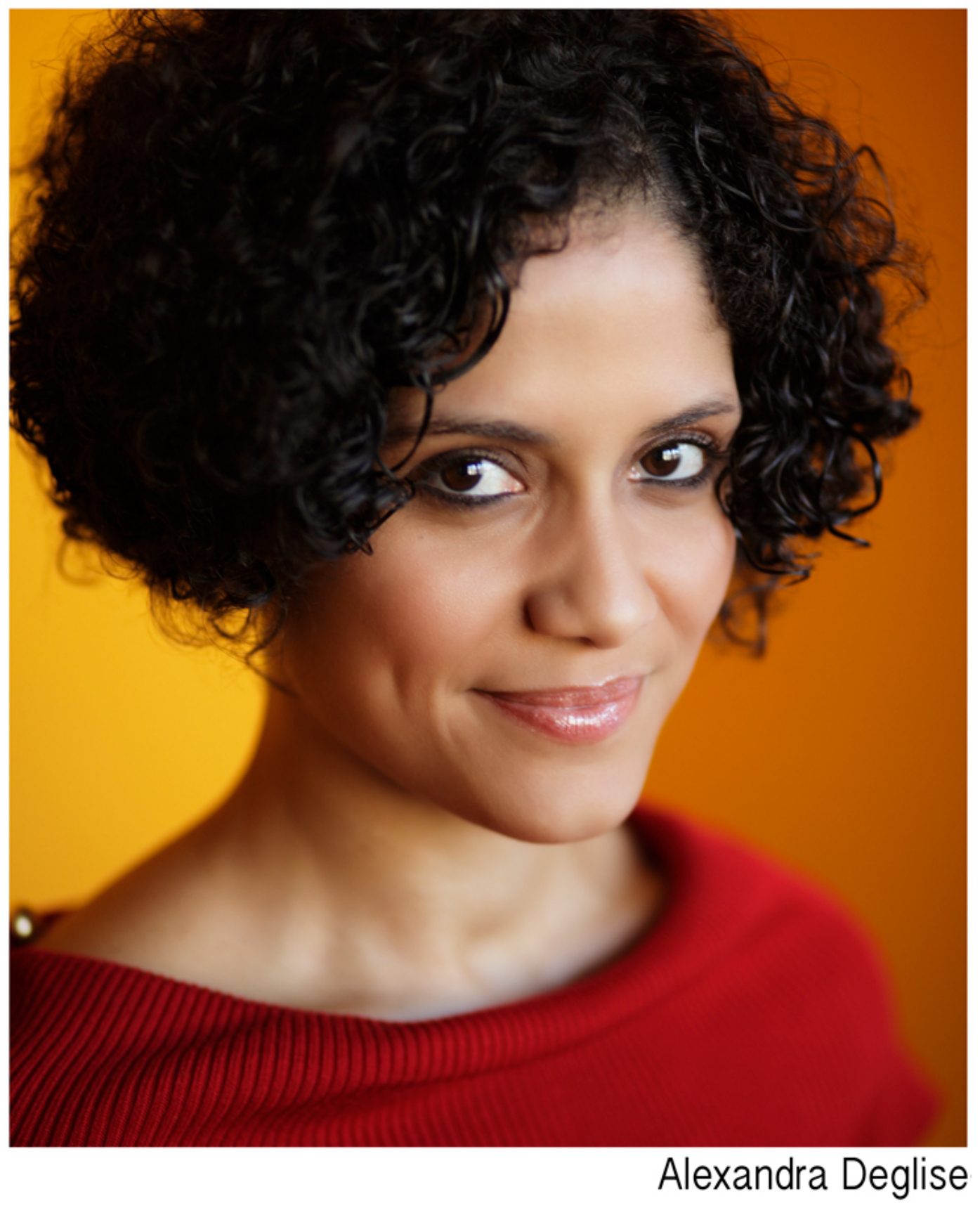




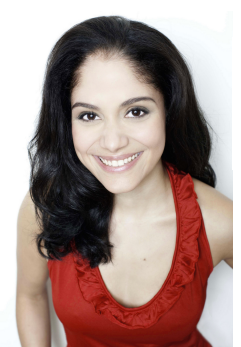

THEATER

Summer and Smoke

Luv

The Sweetest Swing in Baseball

9 Parts of Desire

W/E: A Theatrical Piece of the Wall

The Blue Room

Win/Lose/Draw

Two Rooms

Rosemary with Ginger

Savage in Limbo

Pizza Man

\section{FILM / TELEVISION}

Où avais-je la tête?

Monotone!

Thank U New York

Losers

HighTecHebdo (Weekly Web Show)

The Ghost of Shakespeare (Web)

The Neti Pot (Music Video)

Maine MoFo (Music Video)

Dime Todo (Music Video)

\section{COMMERCIALS}

Jamies White Realty

Project Link

MiniMode MaxiMode

\section{ALEXANDRA DEGLISE} EMC

\author{
E-mail: ald7rj@virginia.edu
}

Height: 5' 4",

Weight: 122
Virginia Repertory Theater
Heritage Theatre Festival
The Helms Theater (UVa)
The Helms Theater (UVa)
The Helms Theater (UVa)
Theater Production Workshop
The Arthur Theater (T. Schreiber Studio)
The Arthur Theater (T. Schreiber Studio)
The Arthur Theater (T. Schreiber Studio)
Gloria Maddox Theater (T. Schreiber St.)
Gloria Maddox Theater (T. Schreiber St.)

Mercredi Production Filmmaker's Society (UVa) New York Film Academy New York Film Academy New York Financial Press Conniption Fitz Productions Drop Six and Allenwood Productions Squirm + Germ Productions Arawak Productions

\section{TRAINING \& EDUCATION}

Master of Fine Arts in Acting, University of Virginia

Master in Journalism, Université Jean Moulin Lyon 3 / Exchange with Baruch College, NY

Acting: Colleen Kelly (UVa), Susan Pilar, Peter Jensen (Scene Study at T. Schreiber Studio)

Voice and Speech: Mary Kate Burke (Uva), Page Clements (T. Schreiber Studio)

Movement: Marianne Kubik (UVa), Certified Instructor in Body Dynamics (Carol Reynolds, T. Schreiber Studio)

Dance: Modern-Jazz, Ballet, Hip-Hop at Alvin Ailey Extension, Dance New Amsterdam

\section{SPECIAL SKILLS}

Singer (Alto, Mezzo-Soprano), Dancer, Beginner Piano and Guitar Player, Reiki Practitioner, Horseback Rider, Driving License (Stick Shift)

Dialects: French, Hispanic, Middle Eastern

Fluent in French and Martinican Creole, Beginner level: Spanish, Portuguese, Japanese

Financial TV and Radio Reporter (France 24 and Europe 1), Camera Operator, Video Editor 


\section{ALEXANDRA DEGLISE'S BIO}

Originally from France/Martinique, Alexandra is an actor, a movement artist and a media professional. She has an Acting M.F.A. from the University of Virginia, a Master in Journalism from the Université Jean Moulin Lyon 3 and a Bachelor in History from the Université de Bourgogne.

Prior to Virginia she lived in New York City for eight years and trained at the American Academy of Dramatic Arts and at the Terry Schreiber Studio, where she certified in Body Dynamics (movement for actors) in 2011. She has been teaching individual and group classes since then. Alexandra has worked for several years as a financial TV and Radio Journalist, reporting live from the floor of the New York Stock Exchange.

Her most recent theatre credits include Summer and Smoke (Virginia Rep); Luv, (Heritage Theater Festival); 9 parts of Desire (U.Va. Drama); The Sweetest Swing in Baseball (U.Va. Drama). 